\title{
Migration Policy of the V4 in the Context of Migration Crisis
}

\author{
HELENA BAUEROVÁ
}

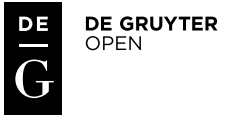

Politics in Central Europe (ISSN: 1801-3422)

Vol. 14, No. 2

DOI: 10.2478/pce-2018-0011

\begin{abstract}
The migration crisis opened up new themes on the basis of the Visegrad Group, which has become the subject of negotiations. Reaction at the EU level showed no/coherence clusters and no/ability to share common positions in negotiations in the EU institutions. There has been a tendency to represent the Central European region as a unit with common interests and needs. The text analyzes 1) the migration policy of the Visegrad Group as a regional organization within the EU and 2) the separate negotiations of the V4 member states at the time of the migration crisis. Our basic assumption for the analysis is the assertion that the Visegrad Group has made it easier for Member States to formulate common positions and objectives in migration policy at a time of migration crisis.
\end{abstract}

Keywords: migration crisis; Visegrad Group; migration quotas; Viktor Orbán; Ewa Kopacz; Robert Fico; Migration Crisis Response Mechanism; effective solidarity

The Visegrad Group was formed as a grouping of the states of Central Europe, the primary goal of which was to return to Europe and enter into the European Union and NATO. In 2004, when this primary goal and the significance of cooperation between the four countries of the region was fulfilled, the question arose concerning whether there was a relevant reason for this group, founded under the Visegrad Declaration, to continue on in its activities. Entrance into the EU, however, opened up a number of new topics that have strengthened V4-based cooperation. These topics were political and economic, but also dealt with culture and foreign policy. In 2015, the platform for shared discussion expanded to include a new topic: migration policy implemented within the 
EU and among V4 members; this also dealt with countries that are situated on migration routes (countries of the Western Balkans, Syria, Iraq, or countries on the African continent).

The migration crisis pointed out the in/coherency of the group and the in/ ability to share mutual stances in negotiations within EU institutions. There appeared a tendency to represent the region of Central Europe as a unit that has shared interests and needs. On the contrary, it is also necessary to point out individual and specific aspects that the migration crisis revealed. This specifically concerns the separate steps of the political elites who, led by varying motives, implemented their own policy independent of the V4. The migration crisis revealed a weakness in the V4's operation that had been the subject of criticism of the group's operation since it was founded - its informal character. The group functions on a voluntary basis and the willingness to negotiate and share mutual interests.

When studying the operation of the V4 in the context of the migration crisis, it is therefore necessary to follow it on two levels. The first is the V4's policy as a regional organization that compounds the interests of the four countries and reacts to EU policy (in this chapter, this concerns dealing with the migration crisis). The second level is represented by individual V4 members - The Czech Republic, Hungary, Poland, and Slovakia.

The following text will analyze the activities of the V4 in the period of the migration crisis, i.e. in the period starting at the end of 2014 until the end of 2016 (and partially overlapping into 2017) in the context of EU activities. Special attention will be paid to the difference between activities in terms of individual states. The Visegrad Group will be presented as a unifying entity in which member states make use of shared interests stemming from their geographical location and cultural proximity in order to more easily promote their interests on an EU level. The primary goal of the text is to analyze the operation of the V4 as an organization that unifies the interests of its four member states. Its preliminary assumption is the hypothesis that the V4 has made negotiations easier between the V4 and the EU in the time of the migration crisis (in the given time frame) and has helped these states to clearly formulate shared stances and goals in terms of European migration policy. As a final consequence, the operation of the V4 in the period of the migration crisis has helped its members emphasize specific needs and point to the significance of the countries in the region.

The following text will be divided into three main chapters. The first will explore V4 policy (shared standpoints, conclusions, and resolutions) in the area of migration policy and its operation on the EU level. The second will analyze the policy of the four V4 members in the field of migration with special consideration to the specific characters relating to each given state. The final chapter will analyze how the shared interests of the V4 members have been reflected in relation to the EU. 


\section{Migration crisis, European Union, and the Visegrad Group}

Discussion on the issue of the migration crisis began at the end of 2014 and beginning of 2015 as migrants primarily from Africa and Syria began to arrive to EU space with heightened frequency. A large number of migrants died en route across the Mediterranean and the European Council labeled the situation tragic (European Council statement 2015). The EU's first reaction was a very careful one; in addition to cooperation with the countries of origin, this dealt with relocation programs based on the voluntariness and willingness of the member states to cooperate. ${ }^{1}$ Several exceptions aside, it was not possible to observe a strong reaction on the part of the member states. This specifically involved Greece and Italy, as these two states were exposed to the largest pressure by migrants. V4 countries expressed their condolences for the victims but did not develop any greater activity. The EU launched a more active policy in May 2015 by declaring the European Agenda on Migration (European Commission 2015), which introduced and referred to the shared responsibility and solidarity between members states of the EU. In the spirit of solidarity, it defined the number of migrants that were to be relocated from Italy and Greece to the other member states of the EU. This was not a voluntary engagement in dealing with the migrant crisis but an effort to involve all member states into a mandatory relocation mechanism.

These changes in the activities of the EU evoked a reaction from $\mathrm{V} 4$ countries, which triggered a more active approach to this issue in June 2015. The first mention of migration is included in the Program of the Czech V4 Presidency (2015/2016), which speaks of the necessity to find a shared stance on 1) the Agenda on Migration and 2) European legislation on migration (Visegrad Group 2015). At the same time, criticism of European migration policy appeared in the declaration of the heads of government of the V4 countries. These countries interpreted the Agenda on Migration as insufficient, as it did not deal with the problem of transit countries, primarily the states of the Western Balkans. Here it is possible to observe a strong solidarity stemming from long-term interest and partnership with the countries in the region. In addition, V4 countries did not agree with the system of mandatory redistribution of asylum seekers according to set quotas (Visegrad Group 2015a). The V4's mutual declaration pointed to the fact that each state should have the opportunity to decide on the number of migrants in its territory.

In the interest of preserving state sovereignty, the group of member states (including V4 countries) led a debate on the implementation of the quota system into practice. The discussion took place primarily in the summer months of 2015 . The primary topic of the negotiations was the refusal to redistribute $40,000 \mathrm{mi}$ -

1 For more, see European Council meeting on migratory pressures in the Mediterranean (23. 4. 2015). 
grants from Italy and Greece. All members of the V4 refused the quota system; Hungary implemented the most radical solution to the migration crisis (see below) as it had become the third most overloaded country of the EU in terms of the number of migrants on its territory. From June to August, we can observe individual activities of $\mathrm{V} 4$ countries that corresponded to a shared standpoint; these states, however, used these activities for their own "unique" solution to the situation. In other words, with the onset of incoming migrants to Europe, V4 countries began more and more to veer toward their own individual activities, via which they intended to defend the interests of their states. The disagreement with the quota system functioned as a binding element in negotiations with the EU. V4 states acted as a unit defending a mutual standpoint that represented the shared interests of the Visegrad Group's countries. V4 negotiations made it easier to find mutual standpoints, although on a practical level it is evident that each of the states selected a different strategy to deal with the migration crisis.

On the V4 level, the migration crisis was openly dealt with at a special summit in September, 2015. There were two reasons for convening these joint negotiations: 1) the number of migrants that entered the EU illegally over the course of 2015 had reached 1.83 million migrants, while only a total number of 1.25 million migrants had applied for asylum in EU space (European Parliamentary Research Service Blog 2016); 2) the need to react to the "second legislation package" presented by the EU. New European legislation included Hungary among the states that needed to relocate migrants from their territory. In addition, the legislation tightened conditions for refusing relocation rules (Council of the EU 2015). V4 states were interested in coordinating a mutual standpoint in order to negotiate in a unified manner in the EU (Orbán 2016). The primary goal of the meeting was therefore an effort to find a mutual standpoint on the migration crisis that would be presented during EU negotiations. After the summit, three primary conclusions clearly stemmed from the final declarations of the heads of government of the V4 states. V4 states 1) respect European legislation in the area of migration and asylum policy; 2) V4 states criticize the EU for its inadequate implementation of measures leading to the elimination of the number of migrants in Europe (in terms of country of origin and transit); 3) V4 states accept the principle of solidarity only in regard to the specific nature of each state and therefore refuse the mandatory quota system created within the EU. ${ }^{2}$

Over the course of these summer months, a strong grouping of countries in Central Europe that had long refused to accept the system of mandatory quotas formed in the EU. Negotiations on a V4 level served as a unifying platform that helped to clearly formulate an opinion. The EU was divided into two proverbial camps - countries supporting the system (namely Western European countries)

2 For the whole final declaration: Government of the Czech Republic (2015): Mutual declaration of the heads of government of the Visegrad Group states. 
and countries that were against it (primarily countries of Central and Eastern Europe, i.e. the V4, Baltic States, and Spain). EU representatives and politicians from member states openly criticized the standpoints and policy of the V4 countries. Refusing quotas for dividing up refugees at an EU level was linked to the discussion on changes in the Schengen system. The incongruousness between member states also pointed to weaknesses in integration as such, as an effort appeared within EU member states to give preference to their own state interests over EU-wide interests. The rhetoric of individual V4 politicians did not vary significantly. The rhetoric of $\mathrm{V} 4$ countries considerably intensified after the acceptance of migration quotas and the declaration made by Chancellor Merkel that Germany would not accept the Dublin system in the case of asylum seekers from Syria ${ }^{3}$. For example, Hungarian Prime Minister Orbán openly accused the European Commission, saying that it had: “... in the past ten years implemented left-wing policy allowing free entry into European space. The EU has failed to deal with the situation, the problem is the EU, which is not able to protect itself" (Traynor 2015). Czech President Miloš Zeman made similar comments on EU policy (Security magazine 2015).

Negotiations on the quota system at an EU level continued on in October and November 2015. Consensus had still not been reached at an extraordinary summit of EU ministers of interior (September 14, 2015). All the ministers representing the V4 refused the system suggested by the EU and followed the mutual stance that arose from the extraordinary V4 summit (see above). The final form of refugee quotas was approved at an EU level on September 21, 2015. Three of the four V4 countries did not agree with the proposal - the Czech Republic, Hungary, and Slovakia. Poland accepted the system and did not follow the unified stance agreed upon by the V4 group. Poland's agreement with the quota system clearly points to the informal nature of the arrangements, which were based on joint meetings. Polish Prime Minister E. Kopacz referred to solidarity with the EU and the necessity to perceive decision making on a European level as a commitment for a member country. In regard to the change in political representation in Poland after elections in the autumn of 2015, Polish rhetoric returned to its dismissive stance and also to the opinion platform of the V4 (see below for more on Poland's position on accepted quotas). Slovakia together with Hungary openly refused the system approved by the Council of the EU and linked their negative stance to a complaint submitted to the European Court of Justice (see below). The Czech Republic also refused the quota system, but did not join in with such a "radical" solution as its V4 partners. The primary argument was the Czech Republic's fear of losing its position in the EU (ČSSD

3 Germany decided to accept asylum requests from Syrian refugees although it was clear that it was not the first country in the Schengen Area that these migrants had come through. Germany renounced the so-called Dublin II rule, according to which refugees should be returned to the country where they had first been registered (for more see Dernbach, 2015) 
2015). Poland also refused to join in the complaint, but supported one in 2017 before the European Court of Justice (Institut pro politiku 2017).

At subsequent EU meetings (sessions of the European Council or the Council of the EU), V4 states each time appeared as a unit and represented mutual standpoints in the field of migration policy. At the same time, it should be mentioned that the issue of migrants, countries of origin, and the protection of external borders became a common part of negotiations of V4 countries at all levels (e.g. at the V4 and Korea summit in December 2015; in January 2016 at a meeting with representatives from Slovenia, Serbia, and Macedonia, etc.). Hungary entered the forefront of the discussion as the state most affected by the migration crisis and one to which other $\mathrm{V} 4$ countries were willing to provide security aid. 4

Two summits took place in the beginning of 2016. The January and February summit showed that V4 states are interested in the operation of the Schengen Area and are willing to follow steps proposed by the EU. The representatives of four countries agreed with measures implemented and planned by the EU, e.g. the establishment of European border and coast guards and implementation of a joint EU - Turkey action plan. They also openly backed countries of the Western Balkans, to which they promised to provide aid in handling the massive wave of migration. The relocation mechanism, which continued to be refused by all members of the V4 (Government of the Czech Republic 2016), remained an exception. The summit that took place in February 2016 was also the second extraordinary V4 summit focused on dealing with the migration crisis and was a reminder of the $25^{\text {th }}$ anniversary of the foundation of the Visegrad Group. V4 negotiations showed that the relationship between the EU and V4 in relation to the migration crisis had calmed; openly negative rhetoric came individually from respective $\mathrm{V} 4$ member states.

Discord between the EU and V4 states arose again at the end of April and beginning of May 2016. The European Commission repeatedly opened discussion on revising asylum policy in its report Towards a Reform of the Common European Asylum System and Enhancing Legal Avenues to Europe (European Commission 2016). Among other things, the new law assumed that the use of relocation mechanisms would become common practice and not an extraordinary solution in the time of the migration crisis. This modified European strategy was reflected in the Slovak EU presidency (June-December 2016). During its presidency, Slovakia suggested an alternative system of flexible solidarity with which the V4 countries agreed (see below). In addition, they agreed on the need for cooperation with states on external EU borders and support in renewing the Schengen system. At the end of 2016, a meeting of V4 interior ministers

4 They promised 50 police officers from each $\mathrm{V} 4$ member state. Poland sent five specially equipped vehicles to Hungary (Joint statement of the Visegrad Group Countries 2015). 
took place that summarized stances on the migration crisis shared among the states. The states once again agreed that the mandatory relocation mechanisms or ad hoc solutions are not effective, they do not prevent the entrance of migrants into Europe, and they are dividing EU member states into camps. The primary change suggested by the V4 was the foundation of the Migration Crisis Response Mechanism (MCRM), the primary goal of which is to create an information sharing platform; states can voice their needs and coordinate joint activities linked to migration. The mechanism is open to all EU member states that express interest (Visegrad Group 2016). MCMR's clear ambition is to ensure cooperation between states in the field of migration. On the other hand, it is more of an informal forum that doubles EU activities. In light of the fact that it is a separate project of V4 states, we can expect the mechanism can to be used only in a limited manner by a regional group and will not have a more significant impact on dealing with the migration crisis in a Europe-wide context.

In general, it can be said that V4 countries in the period of 2014/2015-2016 persevered in their negative position toward mandatory quotas. They agreed with the individual efforts by the EU to reform migration and asylum policy, but they criticized it for inconsistency in implementing the law in practice. The resistant stance on mandatory quotas is evident also statistically, as 12 migrants had come to the Czech Republic by mid-2017; 16 came to Slovakia, while Poland and Hungary had none.

\section{Member states of the Visegrad Group and the migration crisis}

The following subchapters will deal with the individual activities of the four V4 member states. ${ }^{5}$ In regard to the abovementioned, it is obvious that states are able to come to an agreement in fundamental matters and present a shared standpoint. On the other hand, however, it is necessary to take into consideration the informal nature of the Visegrad Group. All decisions presented by the V4 are not legally binding. Therefore, individual states can implement individual state policy. At the time of the migration crisis, significant differences appeared, primarily in the tools they used to confront the wave of migration.

\section{Hungary}

Hungary is an ethnically homogenous country ( $92 \%$ of its population are Hungarian) (Population census 2011); Romas and Germans form considerable minorities. A continual growth of the number of foreign migrants can be observed

5 In terms of time and content, the ambition of this chapter is not to analyze in detail the development of migration and asylum policy of V4 countries. Therefore, the subchapters study the current state of migration and asylum policy at the end of 2014 and beginning of 2015 with regard to membership in the EU and subsequently point out un/preparedness to engage in a solution to the crisis on an EU level. 
in Hungary since its entry into the EU. Geographically, migrants settle in the central part of the country and around its capital city; in the southern part of the country, they settle on the border with Serbia and in the northeast on the border with Romania and Ukraine (Kokaisl, 2014: 238-251). The homogenous character of society did not force Hungary to create its own strategy or concept of migration policy. The basis of its migration policy was to respect free movement within the EU, to support the immigration of Hungarians living in neighboring states, and a careful approach to migrants from third countries outside the EU zone. In 2011, a new naturalization law granting Hungarian citizenship to migrants who can prove their Hungarian origins was adopted. A result of the acceptance of this law was a massive growth in the number of requests for acquiring Hungarian citizenship. In 2010, it was "only" 6,086 applications; in 2011-2012 it was 230,000 (Euroskop 2012).

Due to the large number of asylum seekers, Hungary was placed on the list of countries that, similarly to Greece or Malta, arrested illegal migrants. In 2012, a wave of demonstrations for strengthening the rights of asylum seekers took place (the main reservation included e.g. guaranteeing the right to medical care, the right to learn Hungarian, and the need to create rules for the integration of migrants into Hungarian society). The result of public pressure was the acceptance of a new law on asylum, which became valid in 2013 (AIDA, 2013). The newly adopted law was criticized, as it established a rule for detaining migrants without any detailed specification, i.e. it provided space for a wide interpretation of the reasons for detainment.

In regard to the rather passive approach to asylum and integration policy, it can be said that Hungary before the migration crisis was not prepared in terms of its infrastructure or even legislation for the influx of a large number of migrants. For instance, according to the Helsinki Committee, the state of buildings meant to house migrants was critical and the local conditions did not conform to human dignity (Hungarian Helsinki Committee 2013). This clearly led to the problems that Hungary faced before and during the migration crisis.

In 2015, in the context of the migration crisis, Hungary was one of the largest opponents of the mandatory quota system for the redistribution of migrants even before its negotiation on an EU level (in May 2015). Prime Minister Orbán dubbed the plan "mad and unfair" (Euractive 2015d). In Hungary, refusal of European law and resistance to the influx of migrants was strongly linked to nationalistic rhetoric supported by government policy. First, the government issued a controversial questionnaire linking migration with terrorism and accusing European policy of supporting the influx of refugees (ibid). The party in government FIDEZS published (June 2015) a plan for the effective protection of state borders linked to the construction of a border fence (Euractive 2015a). The fence was built on the Serbian-Hungarian border at a length of 175 kilometers. An anti-migration media campaign also took place in the country, the goal of 
which was to discourage asylum seekers. ${ }^{6}$ Prime Minister Orbán made efforts to change Hungarian legislation that would not allow the acceptance of the mandatory quota system in the country. In order to legalize the change, he first chose to hold a referendum. However, registered voter participation was low and therefore, despite its positive result, the referendum was only of a recommendatory nature (National referendum 2016). The refusal of mandatory quotas was and still is a government priority and after the failure of the referendum, the government suggested accepting constitutional amendments. In order to adopt a constitutional amendment in Hungary, it is necessary to possess a 2/3 majority of votes in the legislative body, i.e. the one chamber parliament. Nonetheless, the ruling party FIDEZS did not possess a sufficient amount of deputies during the election period of 2014-2018 and was not successful in elections in gaining the support of the two remaining deputies for a necessary majority (Reuters 2016). A draft constitutional amendment was therefore not accepted. From a long-term perspective, Hungarian politics has refused to deal with the migration crisis on European territory and has given preference to implementing projects in countries of origin or on migration routes. One of its priorities is to support the construction of hot spots beyond the external borders of the EU. After elections in April 2018, the governing party FIDEZS gained a constitutional majority and what amendments will be accepted in the future remains a question.

Hungary selected controversial tools for dealing with the migration crisis also because it was facing the largest number of migrants in terms of V4 countries and the whole EU (in terms of its population). The primary reason for this strong flow of migration was Hungary's location on the primary migration route leading from the Western Balkans through Hungary to Western Europe (primarily do Germany). Hungary was not able to handle the large number of migrants administratively or logistically. In September 2015, the media showed food being divided up in migrant camps by being thrown into the crowd. Registration of refugees and dealing with their situation on the spot also proved to be problematic. The controversial construction of a fence was "accompanied" by the use of the army, which was allowed to use rubber projectiles or tear gas against the migrants. The primary argument made by the government justifying this stance toward migrants was the effort to protect the Hungarian population and Hungarian borders (Virtue - Kegl 2015). After Germany withdrew from the Dublin system for refugees from Syria, special trains were for migrants headed to Western Europe were sent from Hungary, regardless of the fact that these refugees did not have the proper papers. Prime Minister Orbán accused Germany of accelerating the wave of migration to Europe (Euractive 2016c).

6 In Hungary, billboards were hung that read, for example: "If you come to Hungary, you cannot take away Hungarians' jobs" or "If you come to Hungary, you have to respect our culture!" (Kolár 2016). 
The tough stance against relocation mechanisms remained intact, and Hungary has therefore not accepted any refugees according to the established mandatory quotas. Together with Slovakia, Hungary sees the quotas as a tool that endangers their state sovereignty and has joined in the complaint submitted against the decision to instate a mandatory relocation mechanism. Proceedings on the failure to fulfill obligations stemming from European legislation commenced in 2017 with Hungary, the Czech Republic, and Slovakia (Denková 2017). The V4 states continued to insist on the ineffectiveness of the relocation mechanisms that will (or will not) help to solve the situation in Italy and Greece. However, in September 2017, the European Court of Justice (ECJ) issued a decision of refusal of the submitted complaint, based on which all member states and thus Hungary and Poland, must act in agreement with the decision of the Council of the EU.7 There is a danger that proceedings will be brought against Hungary before the Court of Justice of the EU.

\section{Czech Republic}

From a long-term standpoint, the Czech Republic is an ethnically homogenous state. The majority of foreigners are geographically concentrated in Prague, the Moravian-Silesian Region, and the Carlsbad Region (ČSÚ 2016). The Czech Republic launched a more active policy regarding migrants in connection with its entrance into the EU. At the time of the migration crisis, the Czech Republic was neither a target country nor a high-priority transit country in the EU. The Czech Ministry of the Interior has pointed out the fact that the wave of migration has sidestepped the country (Ministry of the Interior 2016). Despite this fact, activities can be observed in the Czech Republic that the state used to defend itself against a large wave of migration. The Czech Republic refuses the system of relocation quotas. According to government rhetoric, relocation is only possible based on the voluntary decision of each state. An example of such activity was a project from 2015, when the Czech Republic adopted a plan to relocate 15 Syrian families from Jordan to the Czech Republic. ${ }^{8}$ The plan, however, was implemented in 2016, when 89 persons were relocated to the Czech Republic. ${ }^{9}$ In light of the failure of the project ${ }^{10}$ (it was terminated in April 2016) ${ }^{11}$ and the

7 For more information on the submitted complaint concerning invalidity and the declaration of the Court of Justice of the EU, see the case law of the Court of Justice, available at: http://curia.europa.eu/juris/ documents.jsf?num=C-643/15.

8 Implementation of the project was covered by the Generace 21charity fund.

9 The project revealed the unwillingness of the majority of refugees to integrate and their attempts to reach neighboring Germany. The project was terminated after four weeks (Ministry of the Interior 2016).

10 The Office of the Government of the Czech Republic (2016): Minutes from the sitting of the Commission for the Rights of Foreigners (19 April 2016).

11 For more on the activities of the Generace 21 charity fund, available at: http://www.gen21.cz/vyrocni-zprava-2015-a-2016/. 
general fact that the Czech Republic is not a target destination for migrants, the Czech government holds a negative stance toward relocation, including voluntary relocation. The country does not view relocation as a tool for dealing with the crisis, as migrants can leave to their country of choice due to open borders (Institut pro politiku a společnost 2015).

The Czech Republic has supported the Slovak proposal of flexible solidarity; nonetheless, in practice it gives preference to financial or technical support in regions migrants are arriving from, engagement in special EU agencies, and focusing on transit countries of the Western Balkans, which are traditional partners. In the period of the migration crisis, the Czech Republic sent several contingents of police officers to overburdened areas in the region, e.g. two contingents to Hungary, five to Macedonia, one to Greece, three to Slovenia, and one to Bulgaria. ${ }^{12}$

The migration crisis is not directly linked to the Czech Republic; however, this issue has been an area that has shaped political debate and public opinion. Primarily Eurosceptic and anti-migration parties have launched a strong campaign addressing the public. This campaign was also reflected in elections to local governments in the autumn of 2016. This included actions by the Dawn Movement, the Block against Islam founded by Martin Konvička, or the Freedom and Direct Democracy movement, which is linked to T. Okamura (Kolár 2016). Czech society has a highly sensitive view of the issue of migrants and links the topic with the threat of terrorist attacks. Society has reacted to official government policy, which has interpreted migrants as a potential security threat. This primarily includes statements linked to former finance minister Andrej Babiš, who took a stance against governing politics, requested for an end to the Schengen system, and expressed wishes to support the Slovak and Hungarian complaint, or the statement made by Czech Interior Minister Milan Chovanec, who also linked migrants to security threats (ČT 2016). Anti-Muslim and populist rhetoric has also come from President Zeman (The Guardian 19. 4. 2016). All asylum seekers are very strictly monitored and only a small number of them meet Czech rules. This is one of the main reasons that the first four refugees were accepted in April 2016 based on mandatory quotas (iRozhlas 2016). By the end of 2017, the Czech Republic had accepted 12 refugees. According to a government declaration, the country would not accept subsequent refugees according to the quota system (Zachová 2018).

The resistant position of the Czech Republic against the quota system lasted over the course of 2016 and 2017. Minister of Interior Chovanec spoke of thoroughly vetting migrants that came to the Czech Republic without the proper documents that would otherwise guarantee their clean record. The autumn

12 The Police of the Czech Republic (2016): Information service: The second contingent on its way to Hungary, cf. Police of the Czech Republic (2016a): Information service: Police are headed for Bulgaria. 
pre-election period (2017) was marked by lingering and heated anti-migration rhetoric presented primarily in the radical statements made by Tomio Okamura's Freedom and Direct Democracy party (SPD). ${ }^{13}$ After the elections, the state's position on EU migration policy remained unchanged. Prime Minister Babiš has refused to accept the idea that the country would not be able to decide on the specific migrants that would be relocated from Italy and Greece. The government has pointed to the large sums it invested into third world countries in the form of developmental aid. Financial aid is interpreted as a tool used to limit the number of potential migrants in source and transit countries. Refusal to fulfill set migrant quotas has led the EC to initiate proceedings with the Czech Republic on the failure to fulfill obligations stemming from European law (proceedings have also been initiated with Hungary and Poland) (Ministry of Interior, Czech Republic 2018). The country is currently (as of March 2018) in danger of sanctions from the EU for failing to fulfill quotas (ČTK 2018) and the initiation of proceedings with the ECJ.

\section{Poland}

Poland is one of the most homogeneous societies in the EU (Cienski 2015). In addition, the majority of Polish society is strongly Catholic; two thirds of its population are actively religious. In the time of the migration crisis, Poland joined the group of states that refused the division of migrants according to mandatory quotas. Prime Minister Kopacz agreed with accepting migrants, but only based on the capacities that each state determines. The basic criterion for accepting migrants in Poland is the religious profile that corresponds to the majority of society. For these reasons, the prime minister gave preference to accepting Christians from Syria (Euractive 2015b).

Poland agreed with V4 partners on not accepting refugee quotas. However, at negotiations in September 2015, it supported the system recommended by the EU. This change in Poland's position can be interpreted in terms of the domestic political situation. The government cabinet led by the Civic Platform, which implemented Prime Minister Ewa Kopacz's policy, expressed its agreement with the European proposal. Kopacz was nominated to her post after the former Prime Minister Donald Tusk was elected president of the European Council. The Civic Platform, which both politicians represented, belongs to a group of pro-European or Euro-optimist parties. Also, close ties between Tusk and Kopacz are evident. Kopacz found herself under pressure that was three-fold - first by the EU, second by Polish society, and third by the V4. The change in Kopacz's stance can be demonstrated in examples of her speeches. In the beginning of September,

13 Radical rhetoric found a response from the electorate, as SPD became the fourth strongest party in the Chamber of Deputies. 
Kopacz declared: "Solutions not taking into account the given country's abilities may prove completely counterproductive. That is why we are against any automatic quotas, but we are willing to talk about the scale of our engagement on voluntary terms" (Radio Poland 2015). Subsequently, on September 4 at a V4 summit, Kopacz agreed with the plan to reject the quota system. On September 12, she stated: "permanent binding quotas would go against the EU spirit of compromise" (Independent 2015). In roughly mid-September, a gradual change in her rhetoric can be observed: "We will show solidarity with those people who are fleeing harm's way or death" (Scally 2015). Finally, she agreed with the mandatory quota system and the dominant governing Civic Platform Party also committed to building ten refugee centers (Deutsche Welle 2015).

The shift from a shared stance among V4 countries did not last long. Change came in Poland very quickly. After elections in October 2015, the opposition conservative-social and Euro-skeptic party Law and Justice took power. The party gained more than $37 \%$ of votes and created a one-color cabinet (Kolár 2016). The new Prime Minister Beata Szydło launched a dismissive and populist policy in which she refused to accept refugees, stating that "thousands of migrants [...] come here only to improve their living conditions." Primarily after the terrorist attacks in Paris (November 2015), she stated that "among these migrants there are also terrorists." Radical statements against migrants are also linked to the Chairman of the Party Jaroslaw Kaczyński, who accused refugees of "bringing in all kinds of parasites, which are not dangerous in their own countries, but which could prove dangerous for the local populations in Europe" (Szczerbiak 2015).

After the Law and Justice Party took power, Poland's rhetoric on quotas returned to the opinion platform of the V4, i.e. the refusal of mandatory quotas. This was joined by strong populism. Poland even retroactively supported the complaint submitted by Slovakia against the system of mandatory quotas (Poland became an intervener in the proceedings). ${ }^{14}$ Poland's resistance is evidenced in the fact that, until the present (March 2018), it has not accepted a single refugee according to the relocation mechanism (Independent 2017). The European Commission is leading proceedings with Poland on the failure to fulfill its obligation stemming from European law.

\section{Slovakia}

Contrary to its V4 partners, Slovakia has had experience with significant minorities (primarily Hungarians and Romas). Its rules for establishing and granting asylum status are very strict. Legislation even after the country's entry into

14 The decision of the Council of the EU on relocation mechanisms was supported in proceedings by Belgium, Germany, Greece, France, Italy, Luxembourg, and Sweden. 
the EU has not changed considerably and harmonization with EU migration and asylum policy has still not been completed. The goal of Slovak integration policy for foreign nationals is to create a homogenous society with one shared Slovak culture. Despite the fact that Slovakia was not a target or transit country during the migration crisis, we can observe very strict rhetoric refusing foreigners on Slovak territory. The government of Robert Fico refused the acceptance of migrants of Islamic faith in the effort to "prevent the creation of a unified Muslim community in the country" (EuroZprávy.cz 2016). The Slovak government linked the argument against the quota system with fears of an influx of individuals from the Arab world.

According to the adopted quota system, Slovakia was to accept a total of 802 migrants from Greece and Italy. Slovak Prime Minister Fico long used harsh rhetoric against European plans to relocate migrants. He dubbed the quota system "dictation" on the part of the EU that violates state sovereignty. At the end of September 2015, the Slovak government accepted and submitted a complaint against the redistribution of refugees among EU member states and directed the complaint toward the European Court of Justice (Office of the Government of the Slovak Republic 2015). Hungary also joined the complaint (see above).

Slovakia (similarly to the Czech Republic) prefers relocation on a voluntary basis, which is linked to the possibility of selecting individual asylum seekers. Religious profile is a condition for the acceptance of migrants to Slovakia. Therefore, the first voluntary relocation program was supported by the Catholic non-profit organization Pokoj a dobro. In December 2015, the first group of Syrian Christian (149 individuals) travelled from Iraq to Slovakia. A portion of the migrants, however, proceeded to return home. ${ }^{15}$ The integration process has confronted a number of problems and cannot be considered successful (Sulovská 2016). Anti-Islamic rhetoric increased after events in Germany on New Year's Eve of 2015. Prime Minister Fico refused the idea of a multicultural Europe, as the influx of migrants increases the threat of terrorism or violence that took place in Germany at the end of 2015 (EuroZprávy 2016).

Slovakia's rhetoric against the EU became more moderate at the time of its presidency in the Council of the EU. As one of the primary opponents of the mandatory quota system, Slovakia suggested its own tool for dealing with the migration crisis that could be used to replace the present system. The plan arose during Slovakia's EU presidency in the second half of 2016. One of the priorities was sustainable EU migration and asylum policy (Programme of the Slovak Presidency 2016) and the subsequent adoption of an "effective solidarity" document ${ }^{16}$, the primary goal of which is to remove arguments within the EU

15 The primary reason for this return home is the fear of foreign culture and the inability to adapt to a foreign environment, especially among the elderly.

16 The original plan spoke of flexible solidarity. 
over the quota system and propose a model that would be acceptable throughout EU member states. The plan stemmed from a three-pillar structure, the basis of which was in identifying the gravity of the situation. The document speaks of normal, worsening, and grave circumstances. None of the situations was linked to the need to use mandatory quotas. The basis upon which the mechanism would operate was the provision of aid that the state had at its disposal, e.g. financial or technical aid or the sharing of asylum seekers. Slovakia based this upon its own experience in which asylum seekers from Austria were accommodated in Slovakia (Geist 2016). The Slovak proposal was not accepted by all states in the EU, e.g. Malta held the presidency in the Council of the EU after Slovakia and did not agree with the proposal. The final report of the European Council states that "effective enforcement of the principle of responsibility and solidarity remains our shared goal" (European Council 2016). The proposal of effective solidarity was supported based on the V4.

The Slovak example shows the willingness to relocate, but only based on the country's own state decision. In addition, the willingness to cooperate with neighboring states that have a large number of migrants on their territory (see cooperation with Austria) is also evident. In 2017, a differing approach toward EU migration policy could be observed in Slovakia. As the only state of the V4, Slovakia decided to react to EU and European Commission pressure and stated the amount of migrants it was capable of accepting. This Slovak decision meant that the European Commission did not launch proceedings on failure to fulfill its obligation (Zachová 2017).

\section{Conclusion}

The issue of the migration crisis revived negotiations and the operation of the Visegrad Four regional group. The decision on mandatory relocation quotas issued by the EU strengthened the ties of these four Central European states. From a long-term perspective, the issue of migration policy has not been one of the areas negotiated in a significant manner on the V4 platform. However, the mass influx of migrants to Europe gave rise to this topic, which has brought all four states of the V4 closer together. Despite the fact that the V4 platform is often interpreted as a non-binding forum, the issue of migration has shown that the topics discussed and the mutual conclusions reached during joint V4 meetings have helped to unify a shared opinion presented during negotiations on an EU level.

The migration crisis has shown two levels of dealing with issues of migration. The first is the level of the Visegrad Group. On this level, V4 states identified their shared interests and goals at the beginning of the crisis that stem from their geographical and cultural proximity. The ability to reach an agreement on a V4 level was clearly shown in the two extraordinary summits devoted to the 
migration crisis and negotiations at the EU plenary, where this common and shared opinion was sustained. Poland's vote to accept the system of mandatory quotas was an exception; in this case, the shared stance was not successfully maintained. At that time, the Polish political scene was influenced by its ties to the president of the European Council and also the pro-European direction of the governing party.

The migration crisis also showed a second, state level, on which states attempt to implement their own policy. It is evident that the V4 countries do not have long-term experience with a larger-scale influx of migrants and that their migration and integration policies (i.e. integrating foreigners into society) are not ready for real use in practice. The acceptance of migrants is linked to the effort to remove all differences and create a homogenous society. A heavy emphasis in all four countries is placed on cultural and often religious symbols and state sovereignty. A sovereign state, according to the conclusions of the V4, has the right to its own definition of solidarity and establishment of rules for the acceptance (or rejection) of migrants or refugees. A common denominator in all four countries is populism, the linking of migrants and terrorism, and fears of Islam on both a level of state politics and society. On a governmental level, statements differ with regard to the structure of government and its stance on European integration. The most radical policy is linked to the Hungarian plan for dealing with the migration crisis, i.e. building a fence and utilization of the army. The strong position of Prime Minister Orbán and populist statements against Germany and the EU should also be mentioned. Hungary is also specific in terms of V4 states, as it is realistically afflicted by the migration crisis, which has revealed the unpreparedness of Hungarian migration and integration policy. On the contrary, Hungary's partners - the Czech Republic, Poland, and Slovakia - were not forced to face an influx of migrants on their state borders. Despite this fact, their rhetoric is similar to that of Hungary. After the election victory of Law and Justice, there has been a special and evident shift in governing politics from a pro-European direction, which was manifested in, for instance, the submission of a complaint against mandatory quotas to the European Court of Justice. The Slovak government supported the complaint and refused mandatory quotas. Nonetheless, Slovakia presented itself more carefully in the period of the EU presidency and presented an alternative plan of flexible solidarity, which was shared ideologically on a V4 level. The last of the V4 countries, the Czech Republic, ideologically shares the conclusions of the V4 and its partners. However, the country has led a more careful policy toward the EU - the official statements of Prime Minster Sobotka, for instance, were not as radical as in the case of the other states studied in this paper. At the same time, it is necessary to follow the rhetoric of various ministers and the country's president, who are similar to their partners in the V4. The year 2017 and the beginning of 2018 have shown that V4 states are still resistant to mandatory quotas and refuse 
the newly proposed reform of EU asylum policy. The only exception is Slovakia, which is not in imminent danger of proceedings before the ECJ, as it agreed to list the number of refugees it is willing to accept in the future.

Although the states examined in this paper presented separate and mutually independent steps to dealing with the migration crisis, it was clearly shown that the V4 platform ideologically unified and supported the shared stances of the four countries in the Central European region. The migration crisis proved that the V4 is a realistic regional player that influences European policy and strengthens local interests. The topic of the migration crisis has intersected a number of areas in which V4 states have found shared interests (e.g. in the area of foreign policy toward countries of the Western Balkans, the protection of external borders, cooperation with EU agencies, etc.). Therefore, it is possible to confirm the hypothesis established in the introduction that claimed that the V4 helped states to defend their interests on an EU level during the period in question. At the same time, the strength of state sovereignty should not be overlooked (e.g. the case of Poland), as it continues to persevere and significantly shape the functioning of the V4.

In relation to European integration and the EU, it is evident that V4 states have created a special grouping that has caused them to be interpreted by Western European states and EU institutions as problematic actors. Failure to respect migration quotas led the European Commission to launch proceedings before the European Court of Justice. In relation to cooperation within the V4, each state has proven to be using its own method of negotiating with the EU in the effort to prevent proceedings from the European Court of Justice.

\section{References}

AIDA (2013): New Law on Asylum Enters into Force in Hungary Allowing Widespread Detention of Asylum Seekers, available at: http://www.asylumineurope.org/news/25-05-2017/new-law-asylum-enters-force-hungary-allowing-widespread-detention-asylum-seekers (15 August 2017).

Cienski, J. (2015): Migrants carry 'parasites and protozoa,' warns Polish opposition leader. In. Politico14. 10. 2015, available at: http://www.politico.eu/article/migrants-asylum-poland-kaczynski-election/ (10 July 2017).

Česká televize (2016): Zeman pod kritikou eurokomisaře: Oslabujete Evropu, available at: http:// www.ceskatelevize.cz/ct24/domaci/1865216-zeman-pod-kritikou-eurokomisare-oslabujete-evropu (23 August 2017).

Český statistický úřad (2016): Cizinci 2016, available at: https://www.czso.cz/csu/cizinci/cizinci-pocet-cizincu (13 August 2017). 
ČSSD (2015): Rozhovor předsedy vlády Bohuslava Sobotky pro deník Právo, available at: https:// www.cssd.cz/data/files/a3-sobotka-pravo.pdf (20 August 2017).

ČTK (2018): Sněmovna: Vláda má v EU zablokovat přerozdělování žadatelů o azyl. available at: http://www.ceskenoviny.cz/zpravy/snemovna-vlada-ma-v-eu-zablokovat-prerozdelovani-zadatelu-o-azyl/1574564 (5 April 2018).

Denková, A. (2017): Czech government insists migrations controls should precede relocation demands. available at: https://www.euractiv.com/section/development-policy/news/czechs-insist-migration-controls-should-precede-relocation-demands/ (5 April 2018).

Dernbach, A. (2015): Germany suspends Dublin agreement for Syrian refugees, available at: http://euractive.com/sections/global-europe/news/germany-sespends-dublin-agreement-for-syrian-refugees (2 July 2016).

Deutsche Welle (2015): Poland abandons promise to take in refugees after Brussels attacks, available at: http://www.dw.com/en/poland-abandons-promise-to-take-in-refugees-after-brussels-attacks/a-19137258 (6 June 2016).

Euractive (2015a): Hungary to build fence at Serbian border, available at: http://www.euractiv. com/section/justice-home-affairs/news/hungary-to-build-fence-at-serbian-border/ (1 June 2016).

Euractive (2015b): Many EU countries say "no" to immigration quotas, available at: http://www. euractiv.com/section/justice-home-affairs/news/many-eu-countries-say-no-to-immigration-quotas/ (1 June 2016).

Euractive (2015c): Orbán says migrant crisis is "Germany's" problem, available at: http://www. euractive.com/section/justice-home-affires/orban-says-crisis-germanys-problem-317316 (3 September 2015).

Euractive (2015d): Hungary's PM Orban calls EU refugee quota plan 'mad', available at: http:// www.euractiv.com/section/all/news/hungary-s-pm-orban-calls-eu-refugee-quota-plan-mad/ (15 May 2016).

European Commission (2015): A European Agenda on Migration. available at: http://ec.europa.eu/ dgs/home-affairs/what-we-do/policies/european-agenda-migration/background-information/ docs/communication_on_the_european_agenda_on_migration_en.pdf (12 May 2016).

European Council meeting on migratory pressures in the Mediterranean (23. 4. 2015), available at: http://www.consilium.europa.eu/en/press/press-releases/2015/04/23-final-remarks-tusk-european-council-migration/ (12 May 2016).

European Council statement (2015): Special Meeting of the European Council, 23 April 2015, available at: http://www.consilium.europa.eu/en/press/press-releases/2015/04/23-special-euco-statement/ (10 May 2016).

European Parliamentary Research Service Blog (2016): Migration and Asylum In the EU: Animated Infographic. available at: https://epthinktank.eu/2016/05/10/migration-and-asylum-in-the-eu-animated-infographic/ (12 May 2016).

Euroskop (2012): 320 tisíc Mad'arů chce mad'arské občanství, available at: https://www.euroskop. cz/8954/21308/clanek/320-tisic-zahranicnich-madaru-chce-madarske-obcanstvi/?ulozit=1 (12 July 2017). 
EuroZprávy.cz (2016): Slovensko rozhodlo: Rázně mění postoj k uprchlíkům. Zemi čekají změny In. EuroZprávy 7. ledna 2016, available at: http://zahranicni.eurozpravy.cz/eu/141882-slovensko-rozhodlo-razne-meni-postoj-k-uprchlikum-zemi-cekaji-zmeny/ (10 July 2017).

Evropská komise (2016): Sdělení Komise Evropskému parlamentu a Radě, Zlepšit společný evropský azylový system a zdokonalit zákonné možnosti, available at: https://ec.europa.eu/ transparency/regdoc/rep/1/2016/CS/1-2016-197-CS-F1-1.PDF (10 August 2017).

Evropská rada (2016): Závěry Evropské rady z 15. prosince 2016, available at: www.consilium. europa.eu/cs/meetings/.../2016/.../20161215-euco-conclusions-finall (12 July 2017).

Flausch, M (2015): Immigrant Crisis causes outcry in Europe. In. Euractive 7. 8. 2015, available at: http://www.euractiv.com/section/justice-home-affairs/news/immigrant-crisis-causes-outcry-in-europe/ (15 May 2017).

Geist, R. (2016): Migrácia: slovenský návrh "efektívnej solidarity" nepresvedčil, available at: https://euractiv.sk/clanky/zahranicie-a-bezpecnost/migracia-slovensky-navrh-efektivnej-solidarity-nepresvedcil (12 July 2017).

The Guardian (2016): Miloš Zeman: the hardline Czech leader fanning hostility to refugees (14. 8. 2016), available at: https://www.theguardian.com/world/2016/sep/14/milos-zeman-czech-leader-refugees (10 August 2017).

Independent (2015): Refugee crisis: Plans to agree quotas to relocate 160,000 asylum-seekers draws rage from Eastern European countries, available at: http://www.independent.co.uk/ news/world/europe/refugee-crisis-plans-to-agree-quotas-to-relocate-160000-asylum-seekers-draws-rage-from-eastern-10498505.html (6 June 2016).

Independent (2017): Poland's Prime Minister says country will accept no refugees as EU threatens legal action over quotas, 17. 5. 2017, available at: http://www.independent.co.uk/news/world/ europe/poland-no-refugees-eu-legal-action-infringement-quotas-resettlement-beata-szydlo-commission-a7741236.html (15 June 2017).

Institut pro politiku a společnost (2015): Uprchlická krize a Česká republika. In. Policy Paper ríjen 2015, available at: http://www.politikaspolecnost.cz/papers/uprchlicka-krize-a-ceska-republika (10 August 2017).

Institut pro politiku (2017): Migrační krize duben-červen 2017. In. Policy Paper, available at: http://www.politikaspolecnost.cz/papers/migracni-krize-duben-cerven-2017 (10 July 2017).

iRozhlas (2016): První Syřané přijatí podle kvót dorazili do Česka. Čekají na udělení azylu, available at: https://www.irozhlas.cz/zpravy-domov/prvni-syrane-prijati-podle-kvot-dorazili-do-ceska-cekaji-na-udeleni-azylu_201604271554_akottova2 (10 August 2017).

Joint statement of the Visegrad Group Countries (2015), available at: https://www.vlada.cz/assets/media-centrum/aktualne/20151015_V4_statement_EuCo_migration.pdf (12 May 2017).

Judikatura Soudního dvora, available at: http://curia.europa.eu/juris/documents. jsf?num=C-643/15 (5 April 2018).

Kokaisl, P. (2014): Etnické minority v Evropě. Praha, Provozně ekonomická fakulta ČZU, 238-251.

Ministerstvo vnitra (2016): Zpráva o situaci v oblasti migrace ke dni 15. dubna 2016, available at: www.mvcr.cz/.../13-zprava-o-situaci-v-oblasti-migrace-ke-dni-15-dubna-2016.aspx (10 August 2017). 
Kolár, T. (2016): The Migration Crisis and the Rise of Right-wing Extremism and Euroscepticism. In. Institute for Politics and Society, Policy Paper, June 2016, available at: http://www.politikaspolecnost.cz/papers/policy-paper-migration-crisis-rise-right-wing-extremism-euroscepticism (13 July 2017).

Ministerstvo vnitra ČR (2018): Souhrnné informace o postupu MV v problematice relokací. available at: http://www.mvcr.cz/migrace/clanek/souhrnne-informace-o-postupu-mv-v-problematice-relokaci.aspx (5 April 2018).

Nadační fond Generace 21: http://www.gen21.cz/vyrocni-zprava-2015-a-2016/ (12 August 2017).

National referendum (2016): Preliminary results, available at: http://valasztas.hu/en/ref2016/ index.html (22 August 2017).

Orbán: Země V4 proberou možnost mimořádného summitu k migraci, iRozhlas, available at: https://www.irozhlas.cz/zpravy-svet/orban-zeme-v4-proberou-moznost-mimoradneho-summitu-k-migraci_201509031936_dpihova (8 August 2017).

Policie ČR (2016): Informační servis: Již druhý kontingent na cestě do Mad'arska, available at: http://www.policie.cz/clanek/jiz-druhy-kontingent-na-ceste-do-madarska.aspx (10 August 2017).

Policie ČR (2016a): Informační servis: Policisté mírí do Bulharska, available at: http://www.policie. cz/clanek/policiste-miri-do-bulharska.aspx (10 August 2017).

Population census 2011, available at: http://www.ksh.hu/nepszamlalas/tables_regional_00 (12 August 2017).

Program slovenského předsednictví (2016), available at: http://www.eu2016.sk/sk/program-a-priority/program-slovenskeho-predsednictva (12 August 2017).

Rada EU (2015): Rozhodnutí Rady 2015/1601, kterým se stanoví dočasná opatření v oblasti mezinárodní ochrany ve prospěch Itálie a Řecka. available at: http://eur-lex.europa.eu/legal-content/CS/TXT/PDF/?uri=CELEX:32015D1601 \& from=EN (16 May 2016).

Radio Poland (2015): PM Kopacz says Poland will not accept refugee quotas, available at: http://www.thenews.pl/1/10/Artykul/219744,PM-Kopacz-says-Poland-will-not-accept-refugee-quotas\#sthash.d5n9WivM.dpuf (6 June 2016).

Reuters (2016): Hungary could ban mandatory EU migrant quotas in November, available at: http://uk.reuters.com/article/uk-europe-migrants-hungary-law-idUKKCN1241M9 (10 August 2017).

Scally, D. (2015): Poland set to vote for harder line on refugees. In. The Irish Times, 24 October 2015. http://www.irishtimes.com/news/world/europe/poland-set-to-vote-for-harder-line-on-refugees-1.2403983 (6 June 2016).

Security magazine (2015): Migrační vlna bude sílit, o svoje hranice se musíme postarat sami, available at: http://securitymagazin.cz/zpravy/migracni-vlna-bude-silit-o-svoje-hranice-semusime-postarat-sami-rekl-prezident-zeman-1404047284.html (2 September 2015).

Sulovská, L. (2016): Uprchlíci opustili Slovensko, vrátili se do Iráku. In. Forum24, available at: http://forum24.cz/uprchlici-opustili-slovensko-vratili-se-do-iraku/?fb_comment_id=117423 6845933518_1174260539264482 (10 June 2017). 
Szczerbiak, A. (2015): How will the European migration crisis affect the Polish election? In. The Polish Politics Blog, available at: https://polishpoliticsblog.wordpress.com/2015/09/26/how-will-the-european-migration-crisis-affect-the-polish-election (23 July 2017).

Traynor, I. (2015): Migration Crisis: Hungary PM says Europe in grip of madness. In. The Guardian 3. 9. 2015. available at: https://www.theguardian.com/world/2015/sep/03/migration-crisis-hungary-pm-victor-orban-europe-response-madness (11 April 2018).

Úrad vlády Slovenskej Republiky (2015): Slovensko podává žalobu voči EU, rozhodnutie Rady ministrov vnútra neakceptujeme, available at: http://www.vlada.gov.sk/slovensko-podava-zalobu-voci-eu-rozhodnutie-rady-ministrov-vnutra-neakceptujeme (22 August 2017).

Úřad vlády České republiky (2016): Zápis ze zasedání Výboru pro práva cizinců 19. 4. 2016, available at: https://www.vlada.cz/assets/ppov/rlp/vybory/pro-prava-cizincu/ze-zasedani-vyboru/ Zapis-ze-zasedani-19--dubna-2016_1.pdf (20 August 2017).

Virtue, R.; Kegl, A. (2015): Hungary calls in the Army: Soldiers given shock powers to use rubber bullets on migrants. In Express 11. 9. 2015, available at: http://www.express.co.uk/news/ world/604332/Hungary-army-powers-to-SHOOT-refugees-migrant-crackdown (19 August 2017).

Visegrad Group (2016): Jointstatement of V4 Interior Ministers on the Establishment of the Migration Crisis Response Mechanism, available at: http://www.visegradgroup.eu/calendar/2016/ joint-statement-of-v4 (13 August 2017).

Visegrad Group (2015): 2015-2016 Czech Presidency: available at: http://www.visegradgroup.eu/ documents/presidency-programs/20152016-czech (15 August 2017).

Visegrad Group (2015a): Joint Statement of the Heads of Government of the Visegrad Group Countries. available at: http://www.visegradgroup.eu/calendar/2015/joint-statement-of-the (15 August 2017).

Vláda České republiky (2016): Státy V4 vyjádřily solidaritu s balkáními zeměmi při řešení migrační krize, available at: https://www.vlada.cz/cz/media-centrum/aktualne/spolecne-prohlaseni-k-migraci-predsedu-vlad-zemi-visegradske-skupiny-140195/ (20 August 2017).

Vláda České republiky (2015): Společné prohlášení předsedů vlád států Visegrádské skupiny, available at: https://www.vlada.cz/cz/media-centrum/aktualne/spolecne-prohlaseni-predsedu-vlad-statu-visegradske-skupiny-134160/(19 August 2017).

Zachová, A. (2017): Soud EU zamítl žalobu Slovenska a Mad'arska proti uprchlickým kvótám. available at: http://euractiv.cz/clanky/aktualne-v-eu/soud-eu-zamitl-zalobu-slovenska-madarska-proti-uprchlickym-kvotam/ (5 April 2018).

Zachová, A. (2018): Česko se chce vyhnout soudu kvůli uprchlickým kvótám s Komisí se zkusí dohodnout. available at: http://euractiv.cz/clanky/cr-v-evropske-unii/cesko-se-chce-vyhnout-soudu-kvuli-uprchlickym-kvotam-s-komisi-se-zkusi-dohodnout/ (5 April 2018).

Helena Bauerová studied Political Science at the Department of Political Science and International Relations, University of West Bohemia in Pilsen/Czech Republic and University of Salford/UK. During he, Ph.D. studies she worked as the Assistant at the Department of Political Science and International Relations, Faculty of 
Philosophy and Arts, University of West Bohemia in Pilsen/Czech Republic. At the moment she is works at Departement of International Relations and European Studies, Metropolitan University Prague/Czech Republic. Her research is concentrated on comparative politics of East and Central Europe and EU internal and external security. She is author or co-author of Politika rozšiřování a země západního Balkánu [Enlargement policy and Western Balkan Countries] (with Ladislav Cabada and Hana Hlaváčková 2014), Bosna a Hercegovina jako konsociační demokracie. Analýza aplikovatelnosti Lijphartova modelu [Bosnia and Herzegovina as a consensual democracy. Analysis of the applicability of the model Lijphart] (2013).

E-mail: helena.bauerova@mup.cz 